\title{
Prevalence of Fasciola hepatica infestation and pathological examination in sheep (Ovis aries) in Dera Ismail Khan
}

\author{
Atiq ur Rehman ${ }^{1}$, Shakeeb Ullah ${ }^{1}$, Muhammad Inamullah Malik ${ }^{1 *}$, \\ Muhammad Umar ${ }^{2}$, Syed Muhammad Kamal Shah ${ }^{1}$, Shakirullah ${ }^{1}$, \\ Muhammad Shuaib Khan ${ }^{1}$, Khalid Muhammad ${ }^{1}$, Muhammad Noman ${ }^{3}$ \\ and Muhammad Naeem ${ }^{1}$ \\ 1. Faculty of Veterinary and Animal Sciences, Gomal University, D.I. Khan-Pakistan \\ 2. Faculty of Veterinary and Animal sciences, Lasbela University of Agriculture, Water and Marine Sciences \\ (LUAWMS)-Pakistan \\ 3. Department of Epidemiology, University of Veterinary and Animal Sciences, Lahore-Pakistan \\ *Corresponding author's email: malikinamgu@gmail.com \\ Citation \\ Atiq ur Rehman, Shakeeb Ullah, Muhammad Inamullah Malik, Muhammad Umar, Syed Muhammad Kamal \\ Shah, Shakirullah, Muhammad Shuaib Khan, Khalid Muhammad, Muhammad Noman and Muhammad Naeem. \\ Prevalence of Fasciola hepatica infestation and pathological examination in sheep (Ovis aries) in Dera Ismail \\ Khan. Pure and Applied Biology. Vol. 9, Issue 1, pp105-111. http://dx.doi.org/10.19045/bspab.2020.90013
}

\begin{tabular}{llll}
\hline \hline Received: 21/06/2019 & Revised: 24/08/2019 & Accepted: 04/09/2019 & Online First: 20/09/2019 \\
\hline \hline
\end{tabular}

\section{Abstract}

Two villages were selected from District Dera Ismail Khan, Kot Sigger at the bank of river Indus and Daraban in the Daman to find out comparative prevalence of Liver fluke and efficacy of anthelmintic (oxfendazole) drugs. 50 sheep were selected from each village and after pretesting, total 32 infested sheep were further randomly divided into 4 equal groups $\mathrm{A}, \mathrm{B}, \mathrm{C}$ and D. Group A were treated with Oxfenda SC (ICI) 1ml per 10kg b.w P.O. Group B was treated with oxfenda SC $1 \mathrm{ml} / 10 \mathrm{~kg}$ in combination with dimadin (Nawan pharma) at $30 \mathrm{ml} / 50 \mathrm{~kg}$ b.w P.O. In Group C (control positive) sheep 5\% glucose were given I.V and in Group D, no drug was used. Faecal and haematological result of each experimental group was examined day 0, 7 and 28. Prevalence of fasciolosis in sheep was 70\% in village Kot Sigger located at the bank of river Indus as compared to Daraban 34\%. Group B sheep treated with two drug combination (oxfenda SC \& dimadin) showed $75 \%$ efficacy as compared to Group A 50\% treated only with Oxfenda SC. At day 0 of the infected group there is significant drop in $(\mathrm{p}<0.05) \mathrm{RBC}$ and HB whereas there was no significant difference found in all groups at day 28. The WBC values were not same in all groups during the treatment, but values become normal after treatment in infested sheep. Similarly the ALT and AST were significantly high $(\mathrm{P}<0.05)$ at day 0 but after treatment the values were same as of control group.

Keywords: Anthelmintic; Liver fluke; Population; Prevalence; Ovis aries Sheep

\section{Introduction}

Pakistan is an agricultural country where livestock have a key role in income of peoples/farmers. Pakistan is the $6^{\text {th }}$ most populous country and had a huge demand for livestock products like milk, meat, eggs and their by-products. The livestock production is heavily affected by some diseases which cause severe drop in both milk and meat. The diseases which affect 
the production vary in their causative agents it may be due to bacteria, helminths, virus and fungus.

The area where snail found in abundant is the most likely environment/place where infection persists in higher rate. Initially snails found in Europe but now a day they are found worldwide and are constant source of infection to animals [1]. The distribution of Galba truncatula (fresh water snail) is mostly abundant in Europe but also found in Pakistan. In Pakistan it is mostly found in tropical $[2,3]$ subtropical climates $[4,5]$ and not found in deserts. As Pakistan lies in temperate zone, snails found round the year [6, 7]. Fasciola hepatica also affects human beings [8].

The eggs shed through faeces of infected animals and confirmed through faecal examination [8]. For diagnostic purpose of fasciola hepatica antigen faeces were used to confirm. The mature fasciola hepatica lays large number of eggs which are excreted out of body through faeces. [10] In water embryonated eggs hatch into miracidia and when snail the intermediate host available penetrate it and develop into sporocyctes, rediae and cercariae. The free swimming cercariae attach to green vegetation and whenever animals graze become infected [11].

The study was conducted with following objectives:

1. To find out the prevalence of fasciola hepatica in sheep's (small ruminant) in district of Dera Ismail Khan.

2. To compare and evaluate the efficiency of anthelmintic drugs in sheep's against the liver flukes.

\section{Materials \& methods \\ Study Area}

In the current study two areas were selected from district Dera Ismail khan (i) village Kot Sigger located at the bank of river Indus and town Daraban, a non-irrigated agricultural land.

\section{Samples collection}

For sampling purpose of the study, 100 sheep's apparently healthy were selected randomly from two already selected villages. During the faecal sample collection, standard protocol was kept in mind and samples were collected from rectum in the month of July. During the selection and sampling none of the sheep was apparently ill neither treated with anthelmintic within 6 weeks.

After samples collection, transported to laboratory and processed within four hours to find out faecal eggs count.

\section{McMaster technique Flotation method}

Test tube containing flotation solution of sodium chloride was used. From faecal samples small amount was put into the test tube after some time the eggs floated on test tube's surface and counting is done under the compound microscope.

\section{Calculations}

(Formula of EGG PER GRAM Count)

Eggs/gm $=\mathrm{X}$

$X=\underline{\text { Total numbers of eggs }}$

No of counting chamber

Based on fasciola hepatica infestation in sheep, all sheep were grouped into three.

$\begin{array}{lc}\text { Highly infested } & 101 \text { and above } \\ \text { Moderate infested } & 11-100 \\ \text { Lightly infested } & 1-10\end{array}$

\section{Haematological and biochemical analysis}

After analysis of feaces samples $n=24$ sheep were found moderate to high infested among 100 sheep with fasciolosis. Then infested sheep were allocated randomly into three groups $\mathrm{A}, \mathrm{B}$ and $\mathrm{C}$ each group containing $n=8$ sheep's. Group $D(n=8)$ was disease free group kept as control negative. Group A treatment was done with Oxfenda SC (ICI)

Group B was treated with oxfend SC and Dimadin (Nawan pharma) in combined form.

Group C was kept as control positive (diseased)

Group D was kept as control negative (disease free)

\section{Efficacy of anthelmintic}

Various anthelmintic drugs' efficacy was determined by taking samples three times 
after treatment at day 0,7 , and 28 by per gram faecal count.

\section{Biochemical and haematological examination}

Sterile syringe was used to collect the blood from the jugular vein of each sheep after treatment at day 0, 7 and 28. Then collected blood transferred into vacutainer containing EDTA. After blood collection different haematological parameters were measured (Haemoglobin, WBC, RBC) by haematological analyser at Faculty of Veterinary and animal Sciences, Dera Ismail Khan. Coulter method was used for hematological analysis [12].

\section{Biochemical analysis}

Biochemical analyser was used for liver function estimation and serum enzyme concentration was found out by alanine aminotransferase (ALT) and aspartate transaminase (AST).

\section{Statistical analysis}

For statistical analysis ANOVA (one way analysis) and SPSS v.13.0 (Duncen multiple range test) was used.

\section{Results}

\section{White Blood Cell Count (WBCs)}

After many days treatment, count of WBCs for sheep of group B was $\mathrm{P}<0.05$ difference while in group $\mathrm{A} \& \mathrm{C} \mathrm{P}<0.05$ difference at only $28^{\text {th }}$ day. Group A, B \& C, Mean values of WBCs count different (significantly) $\mathrm{P}<0.05$ on comparison with group D. On comparison of with group D the mean values of WBCs count at the day 28 were different (significantly) $\mathrm{P}<0.05$.

\section{Red blood cell count (RBCs)}

By the experimental work of many days a significantly difference was found in group $B$ and $C$ of RBCs count. While in sheep of group A significantly difference $(\mathrm{P}<0.05)$ was observed at only day 28. Before initiation of treatment mean values were reported different (significant lower) $(\mathrm{P}>0.05)$ on comparison of with disease free group i.e. group D. on comparison of mean values of day 7 treatment of group A, $\mathrm{B} \& \mathrm{D}$ with positive control group i.e. group $\mathrm{C}$ were $\mathrm{P}<0.05$ (significantly higher).
On comparison of mean values of day 28 treatment of group A, B \& D with positive control group i.e. group $\mathrm{C}$ were $\mathrm{P}<0.05$ (significantly higher). On the last day of treatment when compared with group (D), the mean value of RBCs count was $\mathrm{P}<0.05$ (significantly lower).

\section{Haemoglobin $(\mathrm{Hb})$ concentration}

After experimental work on sheep of group $A$ and $D$ was non-significant difference $(\mathrm{P}>0.05)$ and in group $\mathrm{B}$ significant difference $(\mathrm{P}<0.05)$ was found in $\mathrm{Hb} g / \mathrm{dL}$ concentration. Research end day treatment $\mathrm{Hb} \mathrm{g} / \mathrm{dL}$ concentration was significantly variant $(\mathrm{P}<0.05)$ in sheep of group $\mathrm{C}$ as compared to day 0 treatment. At day 0 , the $\mathrm{Hb}$ concentration of group $\mathrm{A}, \mathrm{B}$ and $\mathrm{C}$ with respect to each other was found $\mathrm{P}>0.05$ and disease free group was found $\mathrm{P}<0.05$. Result of day 7 treatment reveals that the $\mathrm{Hb}$ Mean Value of group A, B and C noted $\mathrm{P}<0.05$ (significantly lower) when compared with $\mathrm{D}$ group while $\mathrm{P}<0.05$ (nonsignificantly) on $28^{\text {th }}$ day of treatment. When research ended A group mean value of $\mathrm{Hb}$ was found $\mathrm{P}<0.05$ (significantly lower).

\section{Biochemical findings \\ Measurement of ASTL $(u / L)$}

In beginning of the treatment at day 0 when mean values of $\mathrm{A}, \mathrm{B}$ and $\mathrm{C}$ group compared with group $\mathrm{D}$ were recorded $\mathrm{P}<0.05$ (significantly higher) and on the end of treatment when mean values were compared with group $\mathrm{C}$ the values were noted $\mathrm{P}<0.05$ (significantly lower).

\section{Efficacy of anthelmintic}

Based upon the commencement of the medical index, EPG, haematological and biochemical examination efficiency of drugs was checked. In group A, two sheep were freed from illness at day7 (25\% drug efficiency) and 4 sheep were freed from illness at $28^{\text {th }}$ day. Combination of anthelmintic preparations was used to treat the sheep of group B and at $7^{\text {th }}$ day, 4 sheep were cured while at $28^{\text {th }}$ day 2 sheep were freed from illness. At day 28 i.e. end of experiment result showed the $50 \%$ and $75 \%$ 
drug efficiency of group A and B respectively.

\section{Prevalence of liver flukes}

Based upon EPG, infection rate of liver fluke at two different areas (Kot Sigger and Daraban) was checked as given in figure 8. The experimental result revealed that 35 faecal sample were +ve (EPG > 200) for liver fluke in Kot Sigger (near Indus river) and 17 were +ve (EPG > 200) for liver fluke in Draban (far urban area) out of 50 from each. At Kot Sigger infection rate was about $70 \%$ as compare to Draban where infection rate was about $34 \%$.

\section{Discussion}

\section{Prevalence rate}

Our result indicates that the areas which are located close to river i.e. have wet lands had higher prevalence than those who are located away and had no wet lands, same is described by the [13-15] downstream river water and flood lead to snail growth which make suitable condition for snail (intermediate host) growth lead to fluke infestation. Same is explained by the [16] that wet and open water ponds and river downstream water make the favourable environment for the snail's growth for fasciola eggs. The prevalence of fasciola hepatica in sheep was high $70 \%$ in village Kot Sigger located at the bank of river Indus as compared to Daraban where $50 \%$. However higher prevalence 100\% [17] and 93\% [18, 19] was reported in previous studies. This high rate of prevalence is probably due to suitable condition for snail growth. The $34 \%$ prevalence was also reported [20] and slightly higher prevalence $37.5 \%$ of $F$. hepatica by another study [21]. Another study was carried out in Quetta Balochistan who reported 50\% prevalence. Similarly, at same city Quetta very low prevalence $3.99 \%$ as reported by some other studies $66 \%$ and $8 \%$ respectively [2224]. These lower rates strongly disagree with our study may be due to different geographical distribution, location of study, weather condition and breed of the animals and different feeding pattern like grazing place. It may be due to relationship between host and parasite as relationship is very important for fluke infestation. Along with the environmental condition, breed and age of animal are also key factors for fluke infestation [25].

\section{Egg per gram}

The severity of infestation mainly determined by the faecal egg per gram. The egg per gram count in our study was 300 in all infected sheep. The closest results were 339 eggs per gram reported by study in Norway [9]. In some studies eggs per gram were higher than ours study results [17]. The possible reason behind the higher egg per gram may be due to heavily snail population in that area.

\section{Efficacy rate}

Determining efficacy of the drug the group B showed satisfactory results with $75 \%$ sheep recovered on the final day $\left(28^{\text {th }}\right)$ of treatment. Oxfendazole SC was given at the rate of $1 \mathrm{ml} / 10 \mathrm{~kg}$ body weight per oral and $1 \mathrm{ml} / 30 \mathrm{~kg}$ body weight per oral. In our study the two-drug combination was used in order to find out best efficiency of drugs for the control of fasciola hepatica as some other researcher also used the sulfadimidine along with other anti-parasitic drug to treat the fasciolosis as sulfadimidine may had some synergistic effect on fasciola hepatic control. It is also possible that our result was not significant, so new drugs combination may also be tried to find out better synergistic drug results than our study $[26,27]$. In group A $50 \%$ efficacy rate of oxfendazole may be due to wrong body weight assessment of sheep which results lower dose calculation of drug. Similarly in some studies drug was given at $5 \mathrm{mg} / \mathrm{kg}$ b.w. and $\mathrm{a} 15 \mathrm{mg} / \mathrm{kg}$ b.w. which result $14 \%$ and $20 \%$ efficacy of drug [28]. A study performed on Australian beef and sheep and a study performed on sheep in Spain also reported same results $[29,30]$ that when oxfendazole administered orally to cows at given @ $12 \mathrm{mg} / \mathrm{kg}$ body weight it kills 6 weeks old fluke and drug efficacy was $97.8 \%, 92.6 \%, 85.4 \%$ and $80.6 \%$ in 
previous studies. There was no information provided about the season and duration of treatment. The difference of EPG of experimental animals may be due to climate, season, age, sex and species of animals.

The clostridium spp grow well in anaerobic condition created when liver cell damaged by fluke larvae's and sulphadiamadin was used with oxfendazole to stop clostridium. When mature liver flukes migrate, they may block the hepatic arteries and vein which results hyperplasia, anaemia and thrombosis [31]. It is supporting evidence that the oxfendazole efficacy can only be improved when it is given in combination with sulphadiamadin.

\section{Haematological findings}

These results are significant and there is an association among the haematological values and liver fluke infestation. Haematological findings ( $\mathrm{RBC}, \mathrm{Hb}$ ) of sheep were significantly lower infected with fasciola and white blood cells (WBC) were significantly higher than the diseasefree group. Similar result has described by previous studies [32] that the fasciola free sheep had normal range biochemical and haematological properties and are agreed with our study. The other studies also support our study result [33] that the sheep affected with fasciola hepatica indicate that the WBC count was high and RBCs and HB level were lower [34] which helped to estimate the disease severity and prognosis of the affected sheep.

\section{Biochemical findings}

Reactive oxygen radicals produced by the liver affected with the fasciola hepatica cause necrosis of liver cells. In our biochemical study we find out that our results are significantly higher than the disease-free group (Group D). These higher biochemical markers were also reported in earlier studies [31].

In previous studies the similar biochemical changes were defined $[33,35,36]$. In the serum of infested sheep, the mean value of aspartate amino transferase (AST) were significantly lower $(\mathrm{P}<0.05)$ which is in disagreement to our findings. The possible reason for lower AST is that the life span of AST in blood plasma is very short. As the duration of study was short it was possible that biochemical parameters did not decreased after treatment as expected it may be decreased after completion of our study duration. As it is known in earlier studies that after eleven weeks of infection AST value reaches to its normal range which supports our findings.

\section{Conclusion}

In the current study two village (Kot Sigger and Daraban) were selected which are located at opposite direction (east-west) $65 \mathrm{~km}$ approx. apart from each other to determine the prevalence of fasciola hepatica and their effective treatment by using various drugs in sheep. Samples were collected three times after treatment at day 0,7 and 28 and per gram faecal count determines the drug efficacy. The sheep were also treated during sample collection in group A Oxfenda SC (ICI) was used. Group B were treated with two drugs oxfenda SC and dimadine (Nawan pharma). Group C was kept as control positive while group D were kept as control negative (disease free). The fasciolosis prevalence among sheep was high $70 \%$ in village Kot Sigger located at the bank of river Indus as compared to Daraban 50\%. The combine effect of two drugs oxfenda SC and dimadin in Group B was found more effective with $75 \%$ efficacy rate than Group A 50\%, treated only with Oxfenda SC. Current study suggested that the fasciola hepatica is more prevalent in marshy, adjust streams and wet lands of river Indus. So, our results strongly suggested that the combine effect of Oxfendazole and Sulphadimide was more effective in fasciolosis treatment in district Dera Ismail Khan, study of this type was conducted first-time in that areas. It was also recommended to carry out same study in cattle in the Dera Ismail Khan for better prevention and control of fasciola hepatica. Awareness should also be created among masses about snails and their control. 


\section{Authors' contributions}

Conceived and designed the experiments: A Rehman, SMK Shah \& S Ullah, Performed the experiments: A Rehman, K Muhammad \& Shakirullah, Analyzed the data: MS Khan \& M Umar, Contributed reagents/ materials/ analysis tools: M Noman \& M Naeem. Wrote the paper: MI Malik.

\section{Refrences}

1. Chen JX, Chen MX, Ai L, Xu XN, Jiao JM, Zhu TJ, Su HY, Zang W, Luo JJ \& Guo YH (2013). An outbreak of human Fascioliasis gigantica in southwest China. PLoS One 8, e71520.

2. Edith R, Godara R, Sharma R \& Thilagar $M$ (2010). Serum enzyme and hematological profile of Fasciola gigantica immunized and experimentally infected riverine buffaloes. Para Res 106: 947-956.

3. McCarty TR, Turkeltaub JA \& Hotez PJ (2014). Global progress towards eliminating gastrointestinal helminth infections. Curr Opi Gastroenter 30: 1824.

4. Walker S, Hoey E, Fletcher H, Brennan G, Fairweather I \& Trudgett A (2006). Stagespecific differences in fecundity over the life-cycle of two characterized isolates of the liver fluke, Fasciola hepatica. Para 133: 209-216.

5. Le TH, Van De N, Agatsuma T, Nguyen TGT, Nguyen QD \& McManus DP (2008) of hybrid/introgressed forms of Fasciola hepatica and Fasciola gigantica in Blair, D. Human fascioliasis and the presence Vietnam. I J Para 38: 725-730.

6. Sargent $\mathrm{R}$, Chambers $\mathrm{M} \&$ Elliott $\mathrm{T}$ (2009). Seasonal differences in the efficacy of pour-on formulations of triclabendazole and ivermectin or abamectin against late immature liver fluke (Fasciola hepatica) in cattle. Veterinary parasitology 161: 133-137.

7. Valero MA, Panova M, Comes AM, Fons $R$ \& Mas-Coma S (2002). Patterns in size and shedding of Fasciola hepatica eggs by naturally and experimentally infected murid rodents. J Para 88: 308-313.

8. Rojas CA, Jex AR, Gasser RB \& Scheerlinck JPY (2014). Techniques for the diagnosis of Fasciola infections in animals: room for improvement. Adv Para 85: 65-107.
9. Domke AVM, Chartier C, Gjerde B, Leine N, Vatn S \& Stuen S (2013). Prevalence of gastrointestinal helminths, lungworms and liver fluke in sheep and goats in Norway. Vet Para 194: 40-48.

10. Durbin C (1952). Longitivity of the liver fluke, fasciola spp in sheep. Proceeding of the helminthological society of Washington 19.

11. Graczyk T \& Fried B (1999). Development of Fasciola hepatica in the intermediate host. Fasciolosis. Dalton JP, Editor. CABI Publishing Oxon: 31-46.

12. Ghazy AE, Gomaa NA \& Nasr NE (2016). Hematological and Biochemical Evaluation in Holstein-Friesian Cows Before and After Surgical Correction of Left Abomasal Displacement on-Filed Condition. Alexandria J of Vet Sci, 49(1): 138-146.

13. Asrat M, Petros B, Jobre $\mathrm{Y}$, Peden D, Shiferaw Y, Taddesse G \& Mamo M (2005). Infection prevalence of ovine fasciolosis in small-scale irrigation schemes along the Upper Awash River Basin.

14. Graber M (1975). Dromedary Parasitosis, Helminths and Helminthiasis of Domestic and Wild Animals in Ethiopia IEMUT, Maison Alfort France.

15. Solomon W (2005). Effect of Strategic anthelmintic treatment intervention on ruminant fascioliasis in Upper Blue Nile Basin, North Western Ethiopia. M.Sc. Thesis, Addis Ababa University. Addis Ababa.

16. Ahmed E, Markvichitr K, Tumwasorn S, Koonawootrittriron S, Choothesa A \& Jittapalapong S (2007). Prevalence of Fasciola spp infections of sheep in the Middle awash River Basin, Ethiopia. Southeast Asi J Trop Med Pub Health, 38: 51.

17. Razzaq A, Islam M, Ahmad S, Shideed K, Shomo F \& Athar M (2012). Prevalence of internal parasites in sheep/goats and effective economic de- worming plan at upland Balochistan, Pakistan. Afri J Biotec 11:12600-12605.

18. Khan K, Munir M \& Khan B (1988). Gross pathology of liver fluke infestation in sheep in and around Quetta Incidence of internal parasites of sheep in upland districts of Baluchistan. MART/AZR project: high elevation research in 
Pakistan: research report no.18, South Asian Association for Regional Cooperation, Islamabad (Pakistan): 22-25 May 1988. AZRI.

19. Razzaq A, Rafique S \& Tareen S (2002). Incidence of internal parasites in sheep and goat at Asghara valley district Ziarat. Balochistan J Agri Sci 3: 43-50.

20. Khan S, Muhammad S, Khan M, Khan M (2015). Study on the prevalence and District, Pakistan. Adv Anim Vet Sci 3: 151-155.

21. Nahed-Toral J, Lopez-Tirado Q, Mendoza-Martınez G, Aluja- Schunemann A \& Trigo- Tavera F (2003). Epidemiology of parasitosis in the Tzotzil sheep production system. Small Rum Res 49: 199-206.

22. Ahmed S, Nawaz M, Gul R, Zakir M \& Razzaq A (2005). Diversity and prevalence of trematodes in livers of sheep and goat in Quetta. Pakistan. Pak J Zool 37: 205.

23. Gargili A, Tuzer E, Gulenber A, Toparlak M, Efil I, Keles V \& Ulutas M (1999). Prevalence of liver fluke infections in slaughtered animals in Trakya (Thrace), Turkey. Turk J Vet Anim Sci 23: 115-116.

24. Saleem M (1985). Haematological studies, serum bilirubin determination, chemotherapy and incidence of fascioliasis in naturally infected sheep.

25. Waruiru R, Kyvsgaard N, Thamsborg S, Nansen $\mathrm{P}$, Bogh $\mathrm{H}$, Munyua $\mathrm{W}$ \& Gathuma J (2000). The prevalence and intensity of helminth and coccidial infections in dairy cattle in central Kenya. Vet Res Communi 24: 39-53.

26. Fairweather I \& Boray J (1999). Fasciolicides: efficacy, actions, resistance and its management. Vet J 158: 81-112.

27. Hutchinson G, Dawson K, Fitzgibbon C \& Martin P (2009). Efficacy of an injectable combination anthelmintic (nitroxynil+ clorsulon+ ivermectin) against early immature Fasciola hepatica compared to triclabendazole combination flukicides given orally or topically to cattle. Vet Para 162: 278-28.
28. Furmaga S, Gundalach J, Sadzikowski A and Paciejewski S (1982). Systamex (oxfendazole) in the treatment of parasitoses of sheep. Med Weter 38: 269271.

29. Brockwell YM, Elliott TP, Anderson GR, Stanton, Spithill TW \& Sangster NC (2014). Confirmation of Fasciola hepatica resistant to triclabendazole in naturally infected Australian beef and dairy cattle. $I$ J Para: Drugs and Drug Resist 4: 48-54.

30. Alvarez-Sanchez M, Mainar-Jaime R, Perez-Garcia $\mathrm{J}$ and Rojo-Vázquez, $\mathrm{F}$ (2006). Resistance of Fasciola hepatica to triclabendazole and albendazole in sheep in Spain. Vet Record 159: 424.

31. Hodzic A, Zuko A, Avdic R, Alic A, Omeragic J \& Jazic A (2013). Influence of Fasciola hepatica on serum biochemical parameters and vascular and biliary system of sheep liver. Iran J Para 8: 92.

32. Kramer J (2000). Normal hematology of cattle, sheep and goats. Schalm's Vet hematol 5: 1075-1084.

33. Matanovic K, Severin K, Martinkovic F, Simpraga M, Janicki Z \& Barisic J (2007). Hematological and biochemical changes in organically farmed sheep naturally infected with Fasciola hepatica. Para Res 101: 1657-1661.

34. Hawkins C (1984). The use of haemoglobin, packed-cell volume and serum sorbitol dehydrogenase as indicators of the development of fascioliasis in sheep. Vet Para 15: 125133.

35. Igado O, Ajala O \& Oyeyemi M (2011). Investigation into the hematological and liver enzyme changes at different stages of gestation in the West African dwarf goat (Capra hircus L.). IJ Anim Vet Adv 3: 277281.

36. Mert H, Kozat S, Ekin S, Mert N \& Yoruk I (2006). Serum sialic acid, lipid bound silaic acid levels in sheep naturally chronic infected with F. Hepetica. Saglik Bilimleri Dergisi 9: 40- 46. 